\title{
Hodgkin Lymphoma by Ann Arbor Stage
}

National Cancer Institute

\section{Source}

National Cancer Institute. Hodgkin Lymphoma by Ann Arbor Stage. NCI Thesaurus. Code C141141.

An anatomic stage for Hodgkin lymphomas based on the Ann Arbor classification criteria. 